\title{
66. A new historicist approach to When We Were Orphans: The representation of memory vs reality
}

\section{Kaya ÖZÇELIK'}

APA: Özçelik, K. (2021). A new historicist approach to When We Were Orphans: The representation of memory vs reality. RumeliDE Dil ve Edebiyat Araştırmaları Dergisi, (24), 1150-1159. DOI: 10.2900o/rumelide.997581.

\begin{abstract}
Emerged as a contemporary form of literary theory in 1980s, New Historicism aims to analyse a text considering not only historical but also socio-cultural contexts as essential background to a literary text. Therefore, New Historicism keeps its own as an approach that aims to reveal the connections between the text and the time it was written, thus to reveal socio-cultural facts of that particular time hidden in a text. Apart from this, New Historicism also functions to lay ground for different analyses of a text from different aspects. One of these functions stands as the interpretation of historical facts by challenging the way how history is evaluated through comparison and/or contrast of how it is reflected as private/personal histories. Stressing on the point that there is not one single history that is interpreted by one single point of view, New Historicism takes attention to unreliability of the history based on the narrator. As a contemporary writer, Kazuo Ishiguro reveals himself as one who focuses on the unreliability of a narrator who feeds on his memories in his novels. Considering all these, this paper aims to analyse Kazuo Ishiguro's When We Were Orphans (2000) to depict how the subjective and unreliable understanding of the history is intermingled with the public history. Thus, it aims to depict how a public history differs from one to another experiencer based on time and memory, and how history is historicised into a personal history differing completely from what it remains in the public history.
\end{abstract}

Keywords: New Historicism, interpretation of history, historicity of texts, textuality of history, memory, Kazuo Ishiguro

\section{Öksüzlüğümüz adlı romana yeni tarihselci bir yaklaşım: Hafizanın gerçekliğe karşı temsili}

$\ddot{O} \mathbf{z}$

1980'lerde çağdaş bir edebi yaklaşım biçimi olarak ortaya çıkan Yeni Tarihselcilik kuramı bir metni sadece tarihi bağlamda değil, aynı zamanda sosyo-kültürel bağlamı da göz önüne alıp bir metni analiz eder. Bu sebeple, Yeni Tarihselcilik, metin ile metnin yazıldığı dönem arasındaki bağlantıları ortaya çıkarmayı amaçlayan bir yaklaşım olarak varlığını korumaktadır, böylece bir metinde gizlenmiş olan o döneme ait sosyo-kültürel gerçekleri ortaya çıkarmayı amaçlar. Bunun dışında, Yeni Tarihselcilik bir metnin farklı açılardan incelenmesi için zemin hazırlar. Bunlardan biri, tarihin nasıl yansıtıldığına meydan okuyarak karşllaştırma ve/veya karşıtlık yoluyla tarihin nasıl özel/kişisel tarihler olarak yansıtıldı̆̆ını yorumlamasıdır. Tek bir bakış açısıyla yorumlanan tek bir tarihin değil, farklı bakış açılarıyla birçok tarihin olduğunu vurgulayarak, Yeni Tarihselcilik, anlatıcıdan yola çıkarak tarihin güvenilmezliğine dikkat çeker. Çağdaş bir yazar olarak Kazuo Ishiguro, romanlarında anılarından

Doktora, Atılım Üniversitesi, Sosyal Bilimler Fakültesi, İngiliz Kültürü ve Edebiyatı Bölümü (Ankara, Türkiye), kayaphillology@gmail.com, ORCID ID: 0ooo-0o01-5648-7186 [Araştırma makalesi, Makale kaylt tarihi: 17.08.2021kabul tarihi: 20.09.2021; DOI: 10.29000/rumelide.997581]

Adres | Address

RumeliDE Dil ve Edebiyat Araştırmaları Dergisi $\quad$ RumeliDE Journal of Language and Literature Studies Osmanağa Mahallesi, Mürver Çiçeği Sokak, No:14/8 Osmanağa Mahallesi, Mürver Çiçeği Sokak, No:14/8

Kadıköy - ÍSTANBUL / TÜRKIYE 34714 Kadıköy - ISTANBUL / TURKEY 34714 e-posta: editor@rumelide.com e-mail: editor@rumelide.com, tel: +90 505 7958124, +90 2167730616 phone: +90 505 7958124, +90 2167730616 
beslenen bir anlatıcının güvenilmezliğini ortaya çıkarmaya odaklanan bir yazar olarak kendisini götermektedir. Tüm bunları göz önünde bulundurarak, bu makale öznel ve güvenilmez tarih anlayışının geleneksel tarihle nasıl iç içe geçtiğini ortaya sermek için Kazuo Ishiguro'nun Öksüzlüğümüz (2000) adlı eserini incelemeyi amaçlamaktadır. Böylece, bir geleneksel tarihin zaman ve hafızaya dayalı olarak bir deneyimciden diğerine nasıl farklılaştığını ve tarihin geleneksel tarihte olduğundan tamamen farklı bir kişisel tarihe nasıl tarihselleştirildiğini göstermeyi amaçlamaktadır.

Anahtar kelimeler: Yeni Tarihselcilik, tarihin yorumlanması, metnin tarihselleşmesi, tarihin metinleşmesi, hafiza, Kazuo Ishiguro

Born in 1954 in Nagasaki, Kazuo Ishiguro keeps his own as not only one of the acclaimed contemporary novelists and a short-story writer in the world of letters but also a musician and a screenwriter. His encounter with the English culture was at the age of five when his father - a physical oceanographer, was offered a temporary position in the National Institute of Oceanography. It was that time onwards that Ishiguro has become an English resident meeting with all opportunities English culture offers. Attending English schools throughout his education years, Ishiguro received his degree in Philosophy, where he majored in English literature at the University of Kent at Canterbury. Ishiguro later studied creative writing on the postgraduate course run by the University of East Anglia. While he has his Japanese links through his family at home, he has also carried English traits through his school and daily life in England. As time went by, his attachment to Japanese culture was not as much and strong as his attachment to English, as he himself notes regarding his English side:

Japan was a very strong place for me because I always believed I would eventually return there, but as it turned out, I never went back. This very important place called Japan which was a mixture of memory, speculation, and imagination was fading with every year that went by. (Krider \& Ishiguro, 1998, p. 150)

In the light cast by these profound and precise summation, Ishiguro comes to view himself as having a "typical English education" and a "typical middle-class Southern English upbringing" (Ishiguro, 2008). However, it was in his early school years that Ishiguro began to feel himself in-between. This would later lead him to feel a "homeless writer"- neither English nor Japanese, but international writer: "I had no clear role, no society or country to speak for or write about. Nobody's history seemed to me my history. And I think this did push me necessarily into trying to write in an international way" (Ishiguro \& Kenzaburo, 1991).

As a Japanese-British novelist - sitting on the hyphen, Kazuo Ishiguro has gained his reputation first with three short stories he published in the anthology Introduction 7: Stories by New Writers (1981). This was followed by other novels he wrote, some of which are as follows: A Pale View of Hills (1982), An Artist of the Floating World (1986), The Remains of the Day (1989; film 1993), The Unconsoled (1995), When We Were Orphans (2000), Never Let Me Go (2005), and The Buried Giant (2015), Klara and the Sun (2021) It was, especially, with the publication of The Remains of the Day that Ishiguro became one of the best-known European novelists at just 35 years of age. Crowned with such prizes as the Royal Society of literature Prize for A Pale View of Hills, Whitbread Book of the Year Award for An Artist of the Floating World, Booker Prize for The Remains of the Days, Ishiguro has lately won the Nobel Prize for Literature for his works that "uncovered the abyss beneath our illusory sense of connection with the world" (Nobelprize.org). Ishiguro also wrote a short-story collection, Nocturnes: Five Stories of Music and Nightfall (2009), and screenplays for British television as well as for the feature films The Saddest Music in the World (2003) and The White Countess (2005) (Birch, 2009, pp. 528).

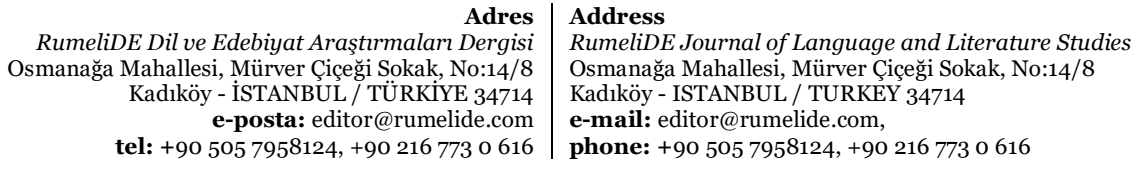


In his quasi-detective novel When We Were Orphans, Ishiguro aims to depict the emotive journeys of memory by intermingling present with the past. Throughout the novel, Ishiguro presents his reader the unreliability of his narrator-protagonist Christopher Banks's memories that shapes his life by not what happened, but by what he believes to have happened. This paper aims to present the relationship between history as a story and memory as represented in the novel by exploring the subjective and unreliable depiction of the fictional character's quest for his personal history that is based on the misleading memories in the light of New Historicism.

When We Were Orphans is a story of a detective - Christopher Banks, an English boy who was born in early-twentieth-century Shanghai's International Settlement. In the novel, the reader is informed that his mother is utterly against opium dealers although his father is involved in profitable business of opium trade. When his parents (first his father then his mother) suddenly disappear, what he thinks for the first time is that they were kidnapped by drug dealers. Orphaned at the age of nine, Banks is sent to England by his uncle Philip to be raised by his aunt. There, he grows up to become a distinguished detective with an idea in his mind to search for his family and meets Sarah Hemmings for the first time. After deciding to solve the bizarre disappearance of his parents, Banks returns to Shanghai in his thirties. When Banks gets there, he is quite shocked at seeing the destruction in the city due to ongoing SinoJapanese war. In all his attempts, he achieves nothing, all the clues he has leads nowhere. In the story, the reader is also introduced to an orphan Jennifer, who has been adopted at an early age by Christopher. Finally, the mystery that Christopher was after for such a long time is solved with the help of Uncle Philip, who reveals the secret that Mr. Banks that his father eloped with his mistress and died in Singapore and his mother was kidnapped by a war Lord as his concubine. However, Banks later finds his mother in a mental hospital in Hong Kong. The novel ends with Banks being content with all realities about his parents after a long time. His only consolation now is his expectation that Jennifer will marry one day and have children. In a nutshell, When We Were Orphans reveals itself as a detective story centred on the character Christopher Banks whose only aim is to find his parents and to fill the gaps in his past by pursuing the secrets with the help of his childhood memories.

To analyse When We Were Orphans in the light of New Historicist approach, it will be appropriate to focus on what Ishiguro says regarding his use of history in the novel. One significant element in Ishiguro's testing the reliability of the narrator is memory of one regarding his past. It is with the help of memory that he can compare the present and past memories that shapes our life:

I'm interested in memory because it's a filter through which we see our lives, and because it's foggy and obscure, the opportunities for self-deception are there. In the end, as a writer, I'm more interested in what people tell themselves happened rather than what actually happened. (King \& Endo, 2012, pp. 261).

Only second to memory in his quest for truth comes the historical events that are always open to be interpreted. That's why Ishiguro most often chooses some historical events and drags his characters into this event so that he can create the right medium of which he can make his character face his/her present memories comparing with what he has in his/her memories, as he puts stress that:

What I started to do was to use history. I would search through history books in the way that a film director might search for locations for a script he has already written. I would look for moments in history that would best serve my purposes, or what I wanted to write about. (Ishiguro \& Kenzaburo,1991, pp. 58)

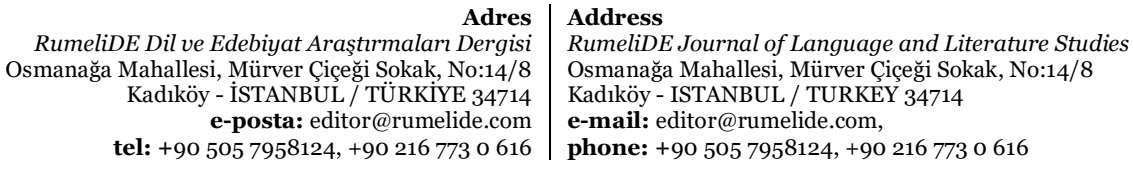

RumeliDE Journal of Language and Literature Studies

Osmanağa Mahallesi, Mürver Çiçeği Sokak, No:14/8

Kadıköy - ISTANBUL / TURKEY 34714

e-mail: editor@rumelide.com,

phone: +90 $5057958124,+902167730616$ 
Based on what he says, it can be suggested that Ishiguro's emphasis on his use of history throughout the novel is simply for two reasons: (1) to provide his reader with the historical background that inspired him to write this novel, and (2) to emphasise the subjective and unreliable understanding of the history that changes from one to another as it changes from period to period. It is through this way that he comes to write a novel which reflects the narrator's search for his personal history based on his unreliable memories as is the case with When We Were Orphans. Although Ishiguro states that he uses history simply for historical background in his novel, the reader notices that it is more than using history as background. The history reflected in the novel can be traced with such references as the Opium Trade, Shanghai International Settlement, and the Sino-Japanese War. Briefly in Chinese history, While Opium Trade alludes to Great Britain's gaining economic power over China through opium trade in $19^{\text {th }}$ century (Trocki, 1999, pp.137), Shanghai International Settlement highlights the settlement that was founded by the British Empire just after the First Opium War, which started due to China's attempt to stop opium trade (Mark, 2017, pp. 13), and the Sino-Japanese War underlines the war between China and Japan which broke out when China resisted Japanese expansion to both Chinese territories and Korea ( Kerr \& Wright, 2015, pp. 608). As is clear, these are all specific historical events recorded in history that Ishiguro refers to. However, Ishiguro does not simply mirror the historical facts but also adds his fictional characters and events to his novel and explores the unreliable account of his narrator's personal history.

In this regard, Jenkins's definition of history as 'one of a series of discourses' has much to do with the discussion of history and reality concerning what New Historicists suggest. Jenkins states in his book Rethinking History (2015) that history and the past are two distinct entities that should not be considered one single unity as he expounds clearly:

The past and history are not stitched into each other such that only one historical reading of the past is absolutely necessary. The past and history float free of each other, they are ages and miles apart. For the same object of enquiry can be read differently by different discursive practices (a landscape can be read/interpreted differently by geographers, sociologists, historians, artists, economists ... etc) whilst, internal to each, there are different interpretive readings over time and space; as far as history is concerned historiography shows this. (pp. 7)

Based on this fact, it can be interpreted that history is the representation of how the past is brought back to present time through several 'discursive practices' that are historicised in books, articles, documentaries or any other means of communication while past is related to an event that happened. This is exactly what New historicist critics mainly concerned with. Defined by Greenblatt as a "practice" rather than a "doctrine", New Historicism suggests that a literary text cannot be evaluated as a concrete separate text ignoring the time it was written and the time it is interpreted (Veeser, 2013, pp. 1). What a New Historicist considers in his analysis of a text is the point that a text is not self-sufficient, but formed by cultural, political, and social events of the time it was written (Munslow, 1997, pp. 31). It is for that reason that there is never ever one reality or truth revealed in a text but many interpretable meanings changing from one individual to another as from one time to another, as Bressler puts it clearly in his book Literary Criticism An Introduction to Theory and Practice (2003) :

As all of society is intricately interwoven, so are the critics and texts, both to each other and in the culture in which the critics live and the texts are produced. Since all critics are influenced by the culture in which they live, New Historicists believe that they cannot escape public and private cultural influences. Each critic will therefore arrive at a unique interpretation of a text. (pp.188)

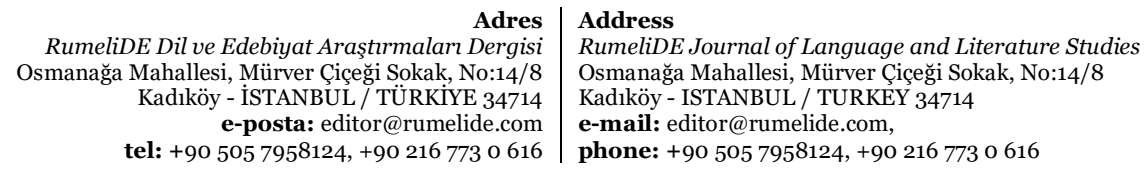


As historiography reveals itself as the retelling of past through several discourses and interpretations from historians' personal viewpoint, according to New Historicists it can be suggested that memories are the past events that rooted in one's mind as blurred remembrance(s) that reflect the past. Therefore, it is possible to analyse unreliability of truth or reality that memories reflect in accordance with what Hutcheon and Foucault put forward respectively. For Hutcheon (2010), there are different ways of understanding a single reality through several discourses: "[t]he real exists (and existed), but our understanding of it is always conditioned by discourses, by our different ways of talking about it" (pp.157). In the same vein, Foucault (p. 117) broadens the discussion by adding that there is no single truth, but 'lack of unified truth' and 'subjective unification of history' shaped by different discourses that change in each episteme through 'discursive formations', as he details further:

We shall call discourse a group of statements in so far as they belong to the same discursive formation; it does not form a rhetorical or formal unity, endlessly repeatable, whose appearance or use in history might be indicated (and, if necessary, explained); it is made up of a limited number of statements for which a group of conditions of existence can be defined. Discourse in this sense is not an ideal, timeless form that also possesses a history; the problem is not therefore to ask oneself how and why it was able to emerge and become embodied at this point in time; it is, from beginning to end, historical - a fragment of history, a unity and discontinuity in history itself, posing the problem of its own limits, its divisions, its transformations, the specific modes of its temporality rather than its sudden irruption in the midst of the complicities of time. (pp. 117)

In short, New Historicist such as Jenkins, Greenblatt, Foucault, and postmodern writer Hutcheon jointly agree that there is no single reality or truth as anyone can analyse any specific facts from his/her different viewpoints regarding what it means, or more correctly, what it reminds him/her at present, as Bressler (2003) suggests that history complete in itself cannot depict the exact truth or picture of the past events on its own (pp.181). In the light of what these theorists suggest on the reliability and objectivity of history, it can also be suggested that memories, too, are unreliable and subjective accounts of the past that can be far from what reality is. Memory is a significant tool for human beings that help understand and shape their lives. In its narrowest meaning, memory is defined as an ability human beings endowed with "to store, retain, and retrieve information, enabling experiences from the past to influence current behaviour" (Murray, Holland \& Kensinger, 2013, Chapter 9). However, it connotes more than its denotative meaning regarding the fact that it is a link between past and present through which one explains his present by making use of past. Beyond this, it defines and unifies human beings, as Teo (2014) explains the significant role it plays:

Memory asserts an enigmatic influence over us. It simultaneously soothes and unsettles us, linking us with our past and our histories while possessing the power to control our future. The role of memory has implications for both the individual and the collective; without memory, we would not have a sense of who we are as individuals, and without the provision of shared memory, a group of individuals would not have a collective identity. (pp.1)

As it reads, it is memory that connects an individual with his history. It serves as a bridge between past and present by which all human beings receive their identity individually or collectively. That's why Ishiguro focuses on "memory and past of the characters in search of an identity, home and self" (Balkaya, 2015, pp. 252 ).

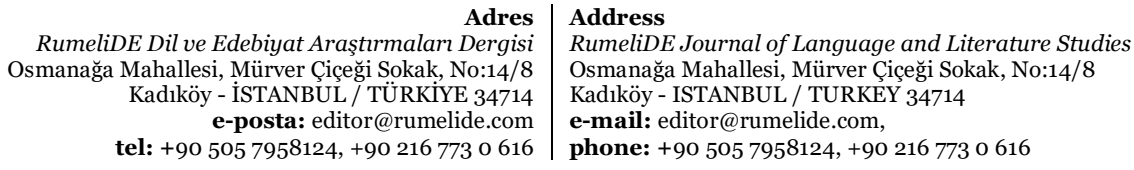


Using memory due to its fragility and misleading potential for subjective truth/reality rather than objective truth/reality as a narrative tool, When We Were Orphans (2000) depicts how memories reflect distorted version of the human mind and the past. In his quasi-detective novel, Ishiguro draws a character whose memory misleads both him and the reader in its fictionalised history of China, including Sino-Japanese war and the import of Indian opium to China by the British. This is clearly confessed many times by the narrator as is here, too: "[c]onsequently, I cannot be sure today how much of my memory of that morning derives from what I actually witnessed from the landing, and to what extent it has merged over time with my mother's accounts of the episode" (Ishiguro, 2000, pp.60).

When the novel is analysed in the light of New Historicism, it is clearly noticed that the novel depicts the 'unreliability' and the 'subjectivity' of truth/reality as a direct result of Ishiguro's use of first-person narration. The real personal history becomes fictional through the misleading memories of the narratorprotagonist Christopher Banks that are always changing. This change is enabled through Ishiguro's use of shifting time. Throughout the novel, there is no linear time. The narrator always goes backward and forward in time, as is depicted in part one and two. In part one, the narrator starts his story telling that "[i]t was the summer of 1923, the summer I came down from Cambridge"; however, the reader notices the date given before the chapter starts as "London, $24^{\text {th }}$ July 1930" (Ishiguro, 2000, pp. 2-3). As is clear, there's a gap of seven years that is never mentioned. For the reader, this is quite problematic in that he cannot decide which date is true. The same unreliability is created in part two which starts with the date "London, 15th May 1931" on the chapter four, but the narrator talks about one of his memories when he and Akira were "around six years old" (Ishiguro, 2000, pp.52).

As is reflected in time, the 'unreliability' and 'subjectivity' of reality/truth can also be noticed in the memories of the protagonist-narrator. The memories that Banks remembers and tells are questionable regarding their reliability. This is depicted well in the scene where Mr. Banks goes to Shanghai in search for his parents. Noticing the big difference between what he remembers and what he sees in Shanghai, he utters:

For the truth is, over this past year, I have become increasingly preoccupied with my memories, a preoccupation encouraged by the discovery that these memories - of my childhood, of my parents - have lately begun to blur. A number of times recently I have found myself struggling to recall something that only two or three years ago I believed was ingrained in my mind for ever. I have been obliged to accept, in other words, that with each passing year, my life in Shanghai will grow less distinct, until one day all that will remain will be a few muddled images. Even tonight, when I sat down here and tried to gather in some sort of order these things I still remember I have been struck anew by how hazy so much has grown. (Ishiguro, 2000, pp.70)

The narrator remembers the time when he played with Akira happily and when he was with his family, but now he knows his reality that he is all alone. Everything has changed and, as a result, he becomes increasingly sceptical of his memories as to whether they are true or not. The novel seems to be serving as a semi-autobiographical work of Ishiguro. As mentioned before, he is an in-between writer - born in Nagasaki, Japan but grew up in England. Although it is wrong to state that Ishiguro is an orphan like his narrator Christopher Banks, he can be regarded as an orphan metaphorically considering his in betweenness'. It is only in this way that one can suggest he seems to draw himself through the narrator Christopher Banks as an orphan who searches for his identity and his personal truth.

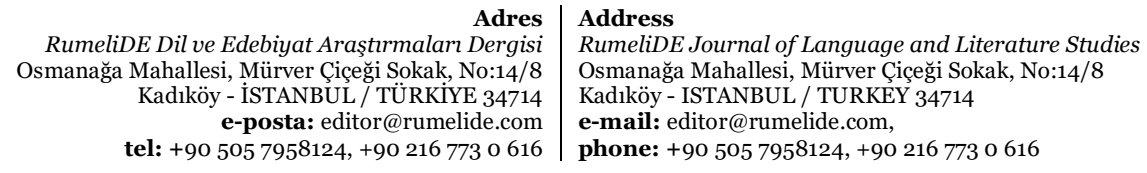


Even within his own memories, Christopher Banks contradicts himself as is seen in the very beginning of the novel where he runs into one of his old friend Osbourne. Although he tells that "[his] own memory is that [he] blended perfectly into English school life", he later rejects this by accepting what Osbourne utters that "I had been an odd bird at school" (Ishiguro, 2000, pp.7). For Christensen, this is a narrative technique that Ishiguro uses in his novel so that he can show how 'unreliable' and 'subjective' one's memories are and how this can continue:

Banks's memories often contradict but invariably displace those that came before. Which is to say that each repetition of a memory is, in an important sense, incommensurate with those that precede it, to the extent that it is grounded in a transformed fantasmatic core that provides its own sense of imaginary continuity. We therefore witness, in the early pages of the novel, a dialectical, performative structure of memory and personal history, for we have, on one hand, a structure of breaks, rendering each memory separate and irreducible, yet oddly interconnected with the others; and, on the other hand, an imaginary sense of the continuity of personal history that is created and re-created with each break. (Christensen, 2008, pp. 210)

In his novel, Ishiguro also fictionalises history by blending the historical background of Second SinoJapanese War with the narrator-protagonist's personal history, namely the memories of the narrator Christopher Banks unlike the way as Hutcheon calls 'historiographic metafiction'. In the novel, reader witnesses the war and see its picture of destruction in Shanghai, but this is not the concern of the novel. It is in fact the way how Ishiguro fills the gaps in his personal history; he presents his reader a historical scene and fills its gaps with his own subjective viewpoints through his fictionalised characters and events based on narrator's unreliable memories. In doing so, Ishiguro represents his reader a fictionalised version of history through the memories that even the narrator himself cannot remember totally. In the same manner as Hutcheon and Foucault emphasise on 'unreliability' and 'subjectivity' of history, Montrose (1989) also emphasises that history cannot be regarded as a real past for simple reason as it is open to many interpretations:

By the textuality of history, I mean to suggest firstly, that we can have no access to a full and authentic past, a lived material existence, unmediated by the surviving textual traces of the society in questiontraces whose survival we cannot assume to be merely contingent but must rather presume to be at least partially consequent upon complex and subtle social processes of preservation and effacement; and secondly, that those textual traces are themselves subject to subsequent textual mediations when they are construed as the "documents" upon which historians ground their own texts, called "histories." (pp. 20)

In the novel, the narrator does never mention any concrete proof, but a history represented by the blurred and insufficient memories that the narrator remembers. Ishiguro's depiction of war and wartime Shanghai suits best to what Montrose suggest. The narrator never gives concrete facts about the war, but he simply depicts it from his own point of view by giving brief information as is seen in the scene where he introduces the reader to Opium Trade and the tumultuous political situation in Shanghai:

In any case, as I say, I spent a good many hours in the British Museum a few years ago gathering material on the history of the opium trade in China, on the affairs of Morganbrook and Byatt, on the complex political situation in Shanghai at that time. I did also, at various points, write off letters to China seeking information unavailable to me in London. So it was that I received one day a yellowed cutting taken from the North China Daily News dated some three years after my departure from Shanghai. (pp. 80)

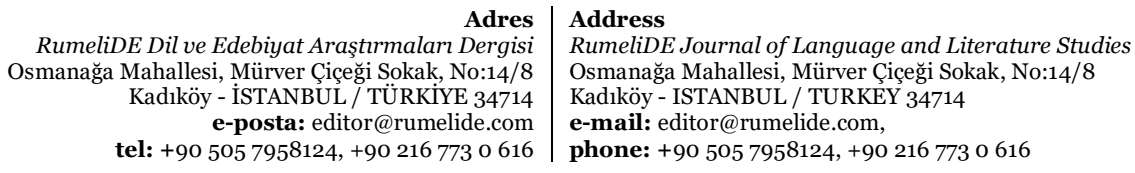


Although the narrator-protagonist is in search of his personal truth throughout the novel, he is entrapped by his misleading memories. This is simply because he does not look for truth in reality, but the truth as it is in his mind. This is well depicted in the scene where Uncle Philip tells him the real truths about his family on contrary to what resides in his misleading memory. In the very beginning when Banks is sent to England to be raised by his aunt, he is told that his parents are kidnapped for their political beliefs. It is this truth that shapes Christopher Banks and pushes him to search for his parents in Shanghai. However, to both the reader and the narrator's surprise, this truth, rooted deep in Banks' memory, is shattered when he is told the realities about his family by his Uncle Philip. The negation of the truths regarding his family that Banks have in his memory starts first with his father. His remembrance of his father as a "Honoured Hero" and his being kidnapped is shattered when he learns the reality that his father in fact eloped with a lady "[y]our father ran off one day with his mistress. He lived with her in Hong Kong for a year, a woman called Elizabeth Cornwallis” (Ishiguro, 2000, pp. 87, 306). Again, the truth about his mother is also shattered. Until he hears from his uncle that his mother has been taken as concubine by Chinese warlord, Banks believes in the truth that she has also been kidnapped (Ishiguro, 2000, pp. 311). As is clear, all truths that Christopher Banks keeps in his memory are destroyed by the real truths that are not in his memory. In doing so, Ishiguro emphasises once again that the memories are not dependable as they are not shaped by the real truths, but subjective truths produced either by an individual or the milieu.

When the novel is analysed as a postmodern writing, this is noticed in the novel in two distinct way: (1) the novel parodies itself as detective novel genre, and (2) it is represented by an unreliable narrator. For W. H. Auden, classic detective novel reveals itself as "a kind of closed world from which evil can be separated and expelled", as Finney quotes in full clarity:

The magic formula is an innocence which is discovered to contain guilt; then a suspicion of being the guilty one; and finally a real innocence from which the guilty other has been expelled, a cure effected, not by me or my neighbors, but by the miraculous intervention of a genius from outside who removes guilt by giving knowledge of guilt. (Finney, 2006, pp.153)

It can be suggested that Christopher Banks adopts what Auden states above, as he states in the novel that "[his] intention was to combat evil - in particular, evil of the insidious, furtive kind" (Ishiguro, 2000, pp. 22). He is in pursuit of those evils who kidnapped his parents throughout the book. Although the novel bears some characteristics of detective genre, it is not a traditional detective novel as "the works of Sir Arthur Conan Doyle, Dorothy Sayers, and Agatha Christie", but a postmodern detective novel due to its "lack of centre" and a "nonsolution" (Delamater \& Prigozy, 1997, pp. 74). Contrary to what expected from a traditional detective novel, Ishiguro goes beyond the limits of the conventions of detective novel genre. Ishiguro uses first person singular narrator throughout his novel, which makes the detective an unreliable narrator in the eyes of the reader. Then, Christopher Banks as a detective does not try to solve the mystery based on some solid evidence, but he directly depends on his fallible memories. Last but not least, the mystery about his parents is solved not by Christopher Banks but by his uncle Philip much to reader's amazement.

All in all, Kazuo Ishiguro's quasi-detective novel tests the tendency to which extent history is reliable. Although he states that he uses history as background in his novel, it is more than this aim. By using history, he enables himself to fill in the gaps from his own perspective that no history book writes by adding some fictional characters and events. By using memory as a narrative tool, Ishiguro also proves how memories can reflect the distorted version of human mind and can change the reality. It is with the

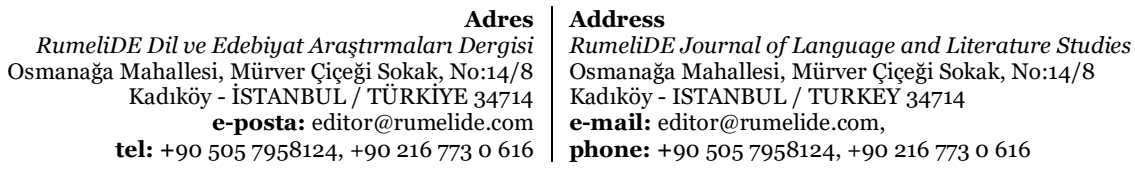


help of this tool that Ishiguro enables his reader to notice that each individual has his own past/history that is liable to change on each occasion and at different times. Considering all these in the light of New Historicism, it can be concluded that both history and memories do not reflect one objective truth, but many subjective truths based on personal understanding of a past event. The novel also proves itself as a postmodern writing with its unreliable narrator, parodying the detective novel genre, and reaching no satisfactory conclusion as expected from the traditional detective novel genre. The narrator's attempt to see the big picture about his parents as a detective fails, which is simply because his detachment from the real truths due to the misleading memories that he nurtures throughout the novel. He cannot find his own true personal history himself but learns it from his uncle Philip when all realities Mr Banks believed in his quest for personal history is revealed as distorted and unreliable facts.

\section{References}

Balkaya, M., A. (2015). Representation of Memory and Nostalgia: Kazuo Ishiguro's When We Were Orphans, International Journal of Language Academy, 3(3), 250-269.

Birch, D. (2009). Oxford Companion to English Literature. Oxford University Press.

Bressler, C. E. (2002). Literary Criticism An Introduction to Theory and Practice. Pearson Longman.

Finney, B. (2006). English Fiction Since 1984: Narrating a Nation. Palgrave Macmillan.

Christensen, T. (2007). Kazuo Ishiguro and orphanhood. The AnaChronisT, 202+. https://link.gale.com/apps/doc/A225938530/AONE?u=anon 8bfaaob5\&sid=googleScholar\&x id=of88fia3

Delamater, Jerome H., and Ruth Prigozy (1997). Theory and Practice Classic Detective Fiction. Greenwood Press.

Dylan Otto Krider, \& Ishiguro, K. (1998). Rooted in a Small Space: An Interview with Kazuo Ishiguro. The Kenyon Review, 20(2), 146-154. Retrieved August 14, 2021, from http://www.jstor.org/stable/4337714

Foucault, M. (2002). The Archeology of Knowledge. Routledge.

Greenblatt, Stephen (1990). "Towards a Poetics of Culture." In H. Aram Veeser (Ed.) The New Historicism (pp. 1-6). Routledge.

Hutcheon, Linda (2010). A Poetics of Postmodernism: History, Theory, Fiction. Routledge.

Ishiguro, K., \& Kenzaburo, Oe. (1991). The Novelist in Today's World: A Conversation. Boundary 2, 18(3), 58, 109-122. doi:10.2307/303205

Ishiguro, Kazuo (2000). When We Were Orphans. Vintage International, Vintage Books.

Ishiguro, Kazuo (2008). Conversations With Kazuo Ishiguro. (Brian W. Shaffer, \& Cynthia F. Wong, Eds.). Univ. Press of Mississippi.

Jenkins, Keith. (2015). Rethinking History. Routledge.

Kerr, A., \& Wright, E. (Eds.). (2015). A Dictionary of World History (3rd ed.). Oxford University Press.

King, R. (2012). "But Perhaps I Did Not Understand Enough": Kazuo Ishiguro and Dreams of Republican Shangai. In King, R., Poulton, C., Endo, K (Eds.), Sino-Japanese Transculturation: From the Late Nineteenth Century to the End of the Pacific War (pp. 261-274). Lexington Books.

Mark, C.-K. (2017). The Everyday Cold War: Britain and China, 1950-1972. Bloomsbury Academic.

Munslow, A. (1997). Deconstructing History. Routledge.

Montrose, Louis A. (1989) "Professing the Renaissance: The Poetics and Politics of Culture." In H. Aram Veeser (Ed.), The New Historicism (pp. 15-36). Routledge.

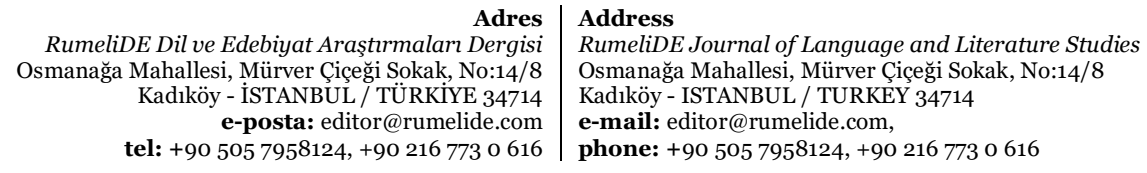


Murray, D. Brendan, holland Alisha C. \& Kensinger Elizabeth A. (2013). Episodic Memory and Emotion. In Robinson, M. D., Watkins, E. R., \& Harmon-Jones, E. (Eds.), Handbook of Cognition and Emotion (pp. 156-175). Guilford Press.

Teo, Yugin (2014). Kazuo Ishiguro and Memory. Palgrave Macmillan.

The Nobel Prize in Literature. (2017). Kazuo Ishiguro. Retrieved January, 2020, from https://www.nobelprize.org/prizes/literature/2017/ishiguro/facts/

Trocki, Carl A. (1999). Opium, Empire, and the Global Political Economy: A Study of the Asian Opium Trade 1750-195o. Routledge.

Adres
RumeliDE Dil ve Edebiyat Araşttrmaları Dergisi Osmanağa Mahallesi, Mürver Çiçeği Sokak, No:14/8 Kadıköy - İSTANBUL / TÜRKIYE 34714 e-posta: editor@rumelide.com tel: +90 $5057958124,+902167730616$
Address

RumeliDE Journal of Language and Literature Studies Osmanağa Mahallesi, Mürver Çiçeği Sokak, No:14/8

Kadıköy - ISTANBUL / TURKEY 34714

e-mail: editor@rumelide.com,

phone: +90 505 7958124, +90 2167730616 